Bilous Victoriia. The main phases of Oleksandr Zupan's development as a geographer and teacher. Journal of Education, Health and Sport. 2021;11(08):438-444. eISSN 2391-8306. DOI http://dx.doi.org/10.12775/JEHS.2021.11.08.049

https://apcz.umk.pl/czasopisma/index.php/JEHS/article/view/JEHS.2021.11.08.049

https://zenodo.org/record/5495973

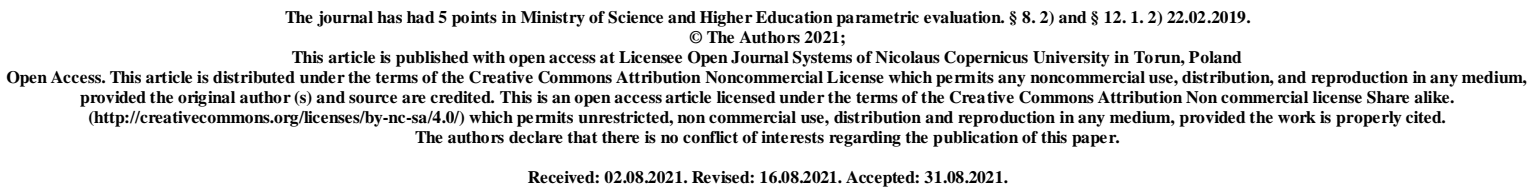

UDC 911.3

\title{
THE MAIN PHASES OF OLEKSANDR ZUPAN'S DEVELOPMENT AS A GEOGRAPHER AND TEACHER
}

\author{
Victoriia Bilous
}

\section{Chernivtsi National University named after Y. Fedkovich}

geobilous@gmail.com

\section{Abstract}

The main phasess of life history and formation of scientific work of Professor Oleksandr Zupan, a famous Austrian geographer, climatologist, teacher, editor of the famous geographical journal "Petermanns Mitteilungen" are described. It is shown the contribution to the development of geographical science, Austrian and German school geography whithin the analysis of O. Zupan's career.

Most of his life Oleksandr Zupan lived in Germany, namely in Gotha. His stay in Slovenia in Ljubljana was very long as well. He studied and worked as a teacher in Ljubljana. In general, we suggest to identify five periods: the first - 1847 - 1869, the second - 1869 1877, the third - 1878 - 1884, the fourth - 1885-1907 years, and the fifth - 1908 - 1920 years.

Key words: Oleksandr Zupan; professor; geographer; climatologist; teacher.

\section{Relevance of the research}

A significant part of his scientific career was spent in Ukraine (northern Bukovina). Oleksandr worked in school, as well as at the University of Chernovtsy. In spite of this, Oleksandr Zupan's figure is little known or not known at all to today's generation of 
geographers of Ukraine. There is no comprehensive analysis of his scientific and public activity till now, although he went through a very complicated historical circumstances of his life and creative activity, Zupan left a significant heritage of physical and economic geography, climatology and history as well as a significant contribution to the development of school geography. Research of scientific and social activity of O. Zupan in the sphere of geography, climatology, history and school geography allows us to speak about the great importance of his ideas for the development of these spheres of knowledge.

\section{An analysis of previous research}

The geography of figures occupies a significant place in the development of the system of geographical sciences. The work of many scientists are devoted to the research in the field of geography. We should mention the following Ukrainian scientists who have made a significant contribution to the study of famous geographers: Y. Olyinik, L. Rudenko, O. Shabliy, V. Rudenko, S. Shevchuk, O. Chubrey, A. Vintonyak and others.

V. Rudenko, D. Segal and D. Ogryn made significant contributions to the O. Zupan's scientific development.

\section{Methodological principles of the research}

The methodological principles of the research are based on general scientific principles of historic authenticity, objectivity, eventuality, and dialectic understanding of the historical process. They are focused on the priority of the documents and scientific works of the scientist, which allow to analyze his activity and to identify the main stages of his formation as a scientist.

We used general scientific analyses (typologization, classification), interdisciplinary (structurally-systemic approach). Historical (problem-chronological, comparatively-historical, descriptive) research methods, cartographic, as well as methods of source analysis and historiographical analysis and synthesis.

\section{Objective of the research}

The purpose of the study is to identify the main stages of Oleksandr Zupan's development as a scientist, who made a significant contribution to the development of geography, climatology and school geography. Objectives: to discover the main stages of Oleksandr Zupan's development as a geographer, teacher, and climatologist; to evaluate and systematize the published sourse base of the scientist; to analyze various spheres of the scientist's socio-geographical development. 


\section{Introduction to the main material}

Studying the scientific activity of Oleksandr Zupan, it should be noted that the scientist had a very complex and rich path to the formation of himself as a scientist. His life path is marked by various events, which played a great role in his formation as a scientist. During his lifetime, Zupan visited various countries, including Italy, Slovenia, Austria, Germany, Ukraine, and Poland.

During his research activity he visited more than 10 cities, where he wrote more than 20 works, some of them were republished several times. Moreover, for a long time he worked as the editor of the famous geographical magazine "Petermanns Mitteilungen", which also published a number of his ideas and studies.

As you can see from Fig. 1, most of his life Oleksandr Zupan lived in Germany (Gotha). He worked as an editor of "Petermanns Mitteilungen". Also, the longest stay was in Slovenia in Ljubljana, where he studied and worked as a teacher. Oleksandr Zupan's stay in Wroclaw, Poland was no less long. In Wroclaw he spent the last years of his life. In Wroclaw he worked as a professor at the University but after a srtoke he was forced to stop teaching. Zupan was born in Iniceni (Tirole), Italy. He spent there his childhood. Oleksandr's work in Ukraine (Chernivtsi) was very important for him. He spent nearly 7 years, teaching first in the Gymnasium, and then at the University. The longest time Zupan spent in Graz, Austria, due to his studies at the University. Once in a while he visited such cities as Halle, Leipzig in Germany and Widen in Austria because he wanted to improve his knowledge.

Working on a chronological sequence of the main stages of Oleksandr Zupan's life, we used his residence, sphere of activity and work, which were issued during this or that period. We suggest to identify 5 periods of Oleksandr Zupan's development as a scientist:

The first stage covers 1847 - 1869: During this period, Oleksandr received his primary education in Brunek in Italy (Tbilisi), and then completed his secondary education at the Gymnasium in Ljubljana, graduating with a diploma [1]. After graduation from the Gymnasium, he received a higher education at the University of Graz, where he began preparing his research "The Final Four Years of Count Ulrich III von Cilli" (published in 1868 in Vienna under the title: Die vier letzten Lebensjahre des Grafen Ulrich III. von Cilli mit besonderer Berücksichtigung der Stände-Revolution in Oesterreich in den Jahren 1451 und 1452. Str. $118+$ karta) [7]. 


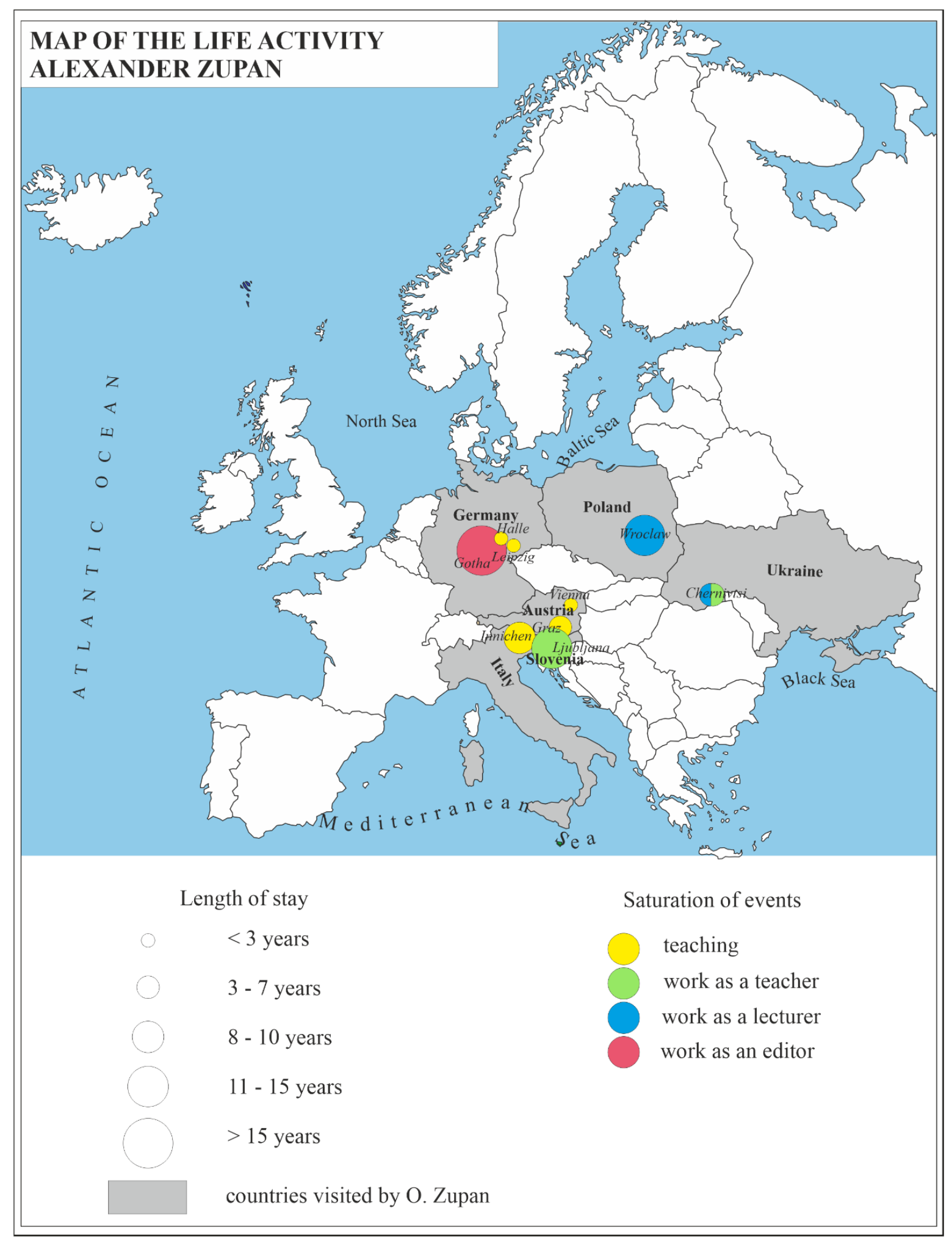

Figure 1. Oleksandr Zupan's life history chart

The second stage - $1869-1877$ - this period is associated with the teaching career at the Ljubljana High School (Laibacher Oberrealschule). In 1874 the first edition of the Lehrbuch der Geographie nach den Principien der neuren Wissenchaft für östererichische 
Mittelschulen (Geography according to the principles of modern science for Austrian Secondary School) was published [9]. This textbook was republished 11 times and adapted to the new ideas about nature and the world. During this period, Oleksandr Zupan continues his studies in Graz and visits the German University Center in Halle, where he studied geology. In addition, he listened to zoological and astronomical lectures in Leipzig [13].

The third period - January 1877 - 1884 - this period can be called a turning point in Oleksandr Zupan's life. He moves to Chernivtsi, where a new stage of his life begins. It can be confidently called the period of the formation and growth of his personality as a scientist and as a teacher. It should be noted that during this period the world saw the fundamental publication - "Fundamentals of physical geography" ("Grundzüge der physischen Erdkunde") [8]. Hhis work was translated into many European languages and was republished 6 times. During this period, he received the title of professor of geography at the Franz Josef University (now the National University of Chernivtsi named after Y. Fedkovich) and started the chain of geography courses at the same University [14].

The fourth phase - 1885-1907. During this period, he moved to Gotha and became the editor of the famous geographical magazine "Petermanns Mitteilungen" [4,5]. During this period Zupan wrote most of his works, including Austria-Hungary, [11] which was published in 1889 in the Collection of Registers. Krichhoff's Collection of Regional Descriptions of Europe and Temperatur zonen der Erde (Temperature Zones on Earth, 1879) [6], where the first map of climatic zones developed by Oleksandr was published. He also published a number of works in the field of climatology and oceanography, polar research, physical geography, economic geography, history and others. In 1886 he was elected a member of the German Academy of Sciences Leopoldin, and in 1904 was awarded the Medal of Cotenius. [2]

Fifth stage - 1908 - 1920. It is final stage of the scientific and pedagogical activity of Professor Oleksandr Zupan. He accepts the offer of the Wroclaw University and moves to Wroclaw, where he starts his teaching activity again [3]. The remaining period of his life he devoted to work in the field of political geography and in the summer of 1918, he published his last work "Leitlinien der allgemeinen politischen Geographie: Naturlehre des Staats" (General Political Geography: Nature Consciousness of State) [10]. Professor Oleksander Zupan died on $6^{\text {th }}$ June, 1920 in Wroclaw, (the Lower Silesian military in Poland).

\section{Conclusion}

There is no future without the past, that's why it is worth to remember the scientists who have made great efforts to ensure us a solid foundation for exploring the world from 
ancient times to the present. Most of his life Oleksandr Zupan lived in Germany and Slovenia. An important stage in Oleksandr's life was his stay in Ukraine (Chernivtsi) where he spent more than 7 years teaching, first in the gymnasium, and then at the University. Having analyzed Zupan's life history, we have identified five stages in his scientific and creative activity: the first stage covers the years 1847 to 1869 . - The first stage covers the period of getting education; the second stage - 1869 - 1877 - a teaching career at the Ljubljana Secondary School; the third stage - 1878 - 1884. - removing to Chernivtsi, where a new stage of his life begins; the fourth stage - 1885-1907 characterized by the growth and maturity of his teaching. - the fourth stage - 1885-1907 - characterized by Oleksandr Zupan's development in the professional field, during this period he moved to Gotha and became an editor of the famous geographical magazine "Petermanns Mitteilungen"; the fifth stage - 1908 - 1920. - The final stage of the scientific and pedagogical activity of Professor Oleksandr Zupan.

\section{References}

1. 3th March - 170th birthday of Austrian geographer and meteorologist Alexander Zupan (Alexander Supan, 3. 03. 1847 - 07. 07. 1920, Wroclaw, today's Poland). The Municipal Library of A. Dobryanskiy. Chernivtsi Library. Peter Demant's bookstore. URL: http://dobrabiblioteka.cv.ua/ua/bukovinskiy-intelektualniikalendar?year=2017\&amp; month=3.

2. Cigale D., Ogrin D. Alexander Georg Supan - v Sloveniji spregledan geograf slovenskega rodu. Dela. 2017. No. 45. P. 135. URL: https://doi.org/10.4312/dela.45.8.135$\underline{163}$

3. Dietrich B. Alexander Supan. Geographische Zeitschrift. 1921. No. 27. P. $193-198$.

4. Kranjec S. Supan, Aleksander Jurij (1847-1920). Slovenska biografija. Slovenska akademija znanosti in umetnosti, Znanstvenoraziskovalni center SAZU, 2013. URL: http://www.slovenska-biografija.si/oseba/sbi630132/\#slovenski-biografski-leksikon

5. Kranjec S. Aleksander Supan, nemški geograf slovenskega rodu. Geografski vestnik. 1963. No. 35. P. 65-69.

6. Supan A. Die Temperaturzonen der Erde. Dr. A. Petermann's Mittheilungen aus Justus Perthes' geographischer Anstalt, 1879, Vol. 25, P. 349-358.

7. Supan A. Die vier letzten Lebensjahren des Grafen Ulrich II. von Cilli, mit besonderer Berücksichtigung der Stände-Revolution in Oesterreich in den Jahren 1451 und 1452. Wien : W. Braumüller, 1868, 118 p. 
8. Supan A. Grundzüge der physischen Erdkunde. Leipzig, Veit \& Comp., 1884, $492 \mathrm{p}$.

9. Supan A. Lehrbuch der Geographie nach den Prinzipien der neuren Wissenchaft für Österrerichische Mittelschulen. Ljubljana (Laibach), 1874

10. Supan A. Leitlinien der allgemeinen politischen geographie. Leipzig : Veit \& comp. , 1918, 140 p.

11. Supan A. Österreich-Ungarn. Länderkunde von Europa / ed. by A. Kirchhoff. Wien, 1889.

12. Supan's Physiography. The Geographical Journal, 1903, Vol. 22, no. 6, P. 694-695.

13. Wagner H. Aleksander Supan. Dr. A. Petermanns Mitteilungen aus Justus Perthes' geographischer Anstalt. 1920. Vol. 66, no. 7/8. P. 139-146.

14. Rudenko V. P. Zupan Oleksandr. Encyclopedia of Modern Ukraine. Kyiv, 2011.VT. 11. P. 45. URL: http://esu.com.ua/search_articles.php?id=14050.

15. Holiavchuk D. Oleksandr Zupan - professor of geography at Chernivtsi National University. Department of physical geography.

URL: http://terra.chnu.edu.ua/aleksandr-zupan-profesor-geografiyi-u-cherniveczkomuuniversyteti/. 